\title{
極東アジア諸国における機械設計に関する テキストの状況調査
}

\author{
Survey on Machine Design Textbooks in Far East Countries
}

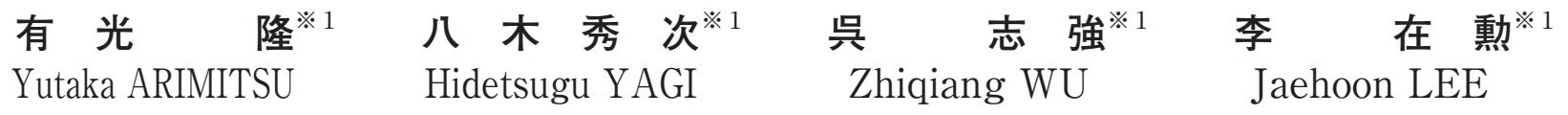

The authors think that engineering textbooks used in Japanese universities have been getting easier. The situation is favorable for beginners because of their basic understanding, but whether learning process is suitable or not is disputable. The authors have been surveying the situation of mechanical design textbooks in Far East Asian countries. Characteristics in these countries are as follows : 1) in China, textbooks in universities whose contents are practical are planed by the state, 2) in Korea, wide ranging contents using translations from English and originals by Korean are employed, 3) in Taiwan, English textbooks using American standards and imperial systems are employed. Since engineering is related to industries and social system, engineering textbooks are reflected by nation's policy and industry.

Keywords : Machine Design Education, Textbook, International Comparison

キーワード：機械設計教育, 教科書, 国際比較

\section{1.はじめに}

学生に対して教科書・参考書の利用状況を調査した ところ,「参考書を購入しない理由」の 1 つに「教科書 だけで十分理解できる」という意見が多くあった ${ }^{1)}$.ま た，図書館の利用について調査したところ，図書館に ある出版年の古い参考書に対して「文字が多く, 堅苦 しい」との意見が散見された。この調查結果から，著 者らは「日本の大学で使用されている教科書は平易化 の方向にある」と考えている。このような状況は初学 者の理解向上の観点から好ましいと考えられるが, 学 習プロセスとして適切であるかどうか議論の余地があ る.このことが動機となって科学研究費補助金に申請 し,「極東アジアにおける機械設計に関するテキストの 状況調査と日本の課題」(2010～2012年度) が採択さ れた。この調査のように近隣の諸外国の教科書を比較 することから，日本における工学教育の問題点もあぶ り出されると考えた.

日本では, 初等・中等教育で用いられる教科書は文 部科学省による検定を受けている，その結果について は分析や評価がマスメディアにより報じられ，多くの 国民が関心を持っている。しかし，大学の教科書につ いて関心を持っている人はほとんどいない。このよう な無関心は，たとえば,「工学教育の質の低下」ひい

2013 年 4 月 4 日受付

※1愛媛大学
ては「日本の産業の衰退」につながる可能性もある. 先進国において若年層の理工系離れは共通した社会現 象であるが，日本の場合には特に顕著である ${ }^{2)}$ 。学生 に期待される理数系学力レベルは以前と同じであるに もかかわらず，それらは低下傾向にある．本研究の目 的の 1 つは「日本の大学に扔ける工学教育の問題」を 提起することにある.

機械設計は実際の機械部品の寸法を決定するための 「力学の応用」という側面と「製造における基礎」の 面とを合わせ持つ。したがって，機械設計の教育方針 には「機械システムか機械要素か」,「実用性か学問性 か」,「現場の技術者向けか学生向けか」などのような 違いが存在する.このような観点の多様性から, 工学 書の中で「機械設計の教科書」を調查対象に選んだ.

極東アジア地域（韓国, 中国, 台湾, 日本）は漢字文 化の影響を受け歴史的に長く交流してきた。 また，近 年は生産の相互依存が高まり技術者・留学生の交流が 活発になっている. 本研究ではこれらの地域での大学 等の高等教育機関の講義で使用されているテキストの 動向について機械設計を中心に調査したものである.

\section{2. 背景となる国情と高等教育の状況の比較}

工学教育はそれぞれの国の産業構造, 大学進学率, 市場の規模などの国情や教育制度に依存することがあ る. また, 大学は企業のニーズを分析し, 政府は科学 振興政策と予算で間接的に技術開発の方向付けを行っ 
表 1 東アジア諸国の国情の比較

\begin{tabular}{|l|r|r|r|r|}
\hline & \multicolumn{1}{|c|}{ 中国 } & \multicolumn{1}{c|}{ 台湾 } & \multicolumn{1}{c|}{ 韓国 } \\
\hline 人口 $^{3)}\left({\left.\mathrm{x} 10^{3}\right)}\right.$ & $1,242,612(00)$ & $22,227(00)$ & $47,279(05)$ & $128,057(10)$ \\
\hline $\mathrm{GDP}^{3)}\left(\mathrm{x} 10^{6} \$\right)$ & $5,739,358(10)$ & $430,096(10)$ & $1,014,369(10)$ & $5,503,527(10)$ \\
\hline 大学数 $^{4)}$ & $2,305(09)$ & $163(11)$ & $334(10)$ & $1,167(11)$ \\
\hline 大学生数 $^{4)}\left(\mathrm{x} 10^{3}\right)$ & $21,446(09)$ & $1,352(11)^{5)}$ & $3,134(10)$ & $2,987(11)$ \\
\hline 工学部学生数 ${ }^{4)}(\%)$ & $36.1(09)$ & $23.7(11)^{5)}$ & $38.4^{*}(10)$ & $15.3(11)$ \\
\hline 大学進学率 ${ }^{4}(\%)$ & $26.5(10)^{6)}$ & $68(11)^{5)}$ & $71(10)$ & $49(11)$ \\
\hline
\end{tabular}

* 理学, 工学, 農学の合計

(10)は 2010 年の統計データを表す。

ている。それゆえ工学の教科書の比較において調查対 象国の国情は重要な要素の 1 つである。表 1 に統計デ 一夕をまとめ, 以下の節において各国の高等教育事情 を紹介する。

\section{1 中華人民共和国（中国）}

中国経済は巨大な国内市場，工業製品の世界規模の 輸出と高い経済成長で特徵付けられる。「中国共産党指 導者層の多くは理系出身である」ということに代表さ れるように，理系出身者の社会的地位が高い。このよ うな社会的背景があり日本のような理系離れが進行し ていない ${ }^{2)}$ 。また, 高等教育機関で工学を学ぶ者の割 合が高い (表 1 参照).

人口や大学数が他の調查対象国に比べて極めて多 く, 大学の教科書という限られた市場に扮いても, そ の読者数は日本の 10 倍程度は存在する.

大学で使用されている教科書は政府により推薦教材 として認定されており, 教育課程の質は中央あるいは 地方政府により評価されている。第 9 次 5 力年計画 （1996-2000）に押いて, 学習者が多い基礎的な分野に ついては「標準的な教科書作成の国家プロジェクト」 が進められた ${ }^{7)}$ 。このように大学教育の内容に国家が 深く関与している.かつては英語のテキストを翻訳し たものが多く使用されていたようだが，国家プロジェ クト以降オリジナルの教科書が出版されるようになっ てきている.

\section{2 中華民国（台湾）}

台湾は国内市場が小さいため, 工業・貿易立国を目 指す政策をとっている．日常は中国語を使用している が，大学の講義には英語の教科書を利用することが多 い. それゆえ西洋諸国の大学院へ留学する学生が多 ( $^{5)}$. オープンユニバーシテイや専門学校を含めると 高校卒業後の進学率は $80 \%$ 以上あり, より良い学歴を 得ようといわゆる受験競争が過熱している。この対策 のために推薦入学や地域枠を設けるなどの対策を講じ ている ${ }^{8)}$.

\section{3 韓国}

工業生産額は大きくないが，製造業に関しては世界 的な企業が多く日本とシェア競争を繰り広げている. 特に電子産業, 自動車産業, 造船や重工業では, 有望
分野への選択的な投資と効率的な生産により世界的な 企業が出現している.このような発展を支えている要 素として「韓国国民の教育に対する熱心さ」と「高い 大学進学率」がある. しかし，1990年代のアジア通貨 危機以降は工学部の志願者が減少しつつある ${ }^{9)}$.

韓国では, 専門の授業のうち 6 割程度は英語のテキ ストを利用し, 残りは翻訳か韓国の大学教員によるテ キストを使用している. しかし, 工業の発展と共に母 国語の教科書が広がりつつある.

\section{4 日本}

国内市場は比較的大きいが天然資源が少ないので, 工業製品の輸出に力を入れてきた１8歳人口の減少と 中学・高校生の理系離れが進み, 工学部への進学希望 者が減少している。 また, 授業で使用されている教科 書は容易化の方向にある。棟語の書籍の市場は英語 に比べはるかに小さいうえに, 専門書のように少ない 読者に対する市場は更に小さい. したがって, 出版業 界はなるべく多くの読者を獲得するために易しい専門 書・入門書に傾倒しつつある. 近年では, 高校生を読 者層としている「大学受験参考書の出版社」が大学の 数学・物理の教科書を出版し始めている.

\section{3. 機械設計の教科書の比較}

\section{1 教科書の外観と概略}

本研究では, 表 2 に示す 22 冊 (中国語: C $1-\mathrm{C} 6$, 韓 国語：K 1-K 7, 日本語 J 1-J 8, 英語（台湾）：E 1） の機械設計の教科書について比較する. 台湾で使用さ れている E 1 以外の全ての教科書は母国語で書かれて いる. これらのうち K $1-\mathrm{K} 4$ は韓国オリジナルのもの で, K 5-K 7 は英語の原典からの翻訳である. 表 2 の 教科書の外観などは表 3 にまとめている. 表 3 におい て, 各教科書の版型が異なるので, 簡単化のために重 量を分量の指標としている. 一般的に日本の教科書は コンパクトで，韓国のものはかなり大きいと言える。

機械設計の教科書は「設計の基礎」,「要素の原理」, 「実際の応用例」「設計上のデー夕」などの内容を含ん でいる．韓国の教科書は応用例や実用データが豊富で 詳細な記述であるので，卒業後の仕事に役立つ．シラ バスによると韓国の機械設計の科目では日本と同じく 
C1: "机械设计基础", 金清肃, 华中科技大学出版社, 2008 .

C2: "机械设计教程 2版", 刘莹, 吴宗泽, 机械工业出版社, 2007.

C3: "机械设计基础 4版", 范顺成, 机械工业出版社, 2007.

C4: "机械设计 2 版", 吴宗泽, 高志, 清华大学精密仪器与机械学系设计工程研究所, 高等教育出版社, 2009.

C5: "机械设计基础 2版", 李威, 机械工业出版社, 2007.

C6: "机械原理与机械设计 上册, 下册, 2版", 张策, 机械工业出版社, 2011.

K1: "종합 기계설계" (総合機械設計), 겅재천, 최상훈, 이용복, 장희싀, 清文閣, 2010.

$\mathrm{K} 2:$ "기계설계" (機械設計), 홍장표, 교보문고, 2009.

K3: "기계요소설계" (機械要素設計), 차흥식, 위금식, 김종삼, 한상희, 알진시, 2011.

K4: "기계설계" (機械設計), 洪性仁, 문운당, 2007.

K5: "기계요소설계", 이종선, 박정선, 배원병, 정일섭, 조용주, 최재봉, 사아텍미디어, 2002. (原典) “Fundamentals of Machine Component Design 3rd Edition", Robert C. Juvinal, Kurl M. Marshek, John Wiley \& Sons, 2000.

K6: "기계설계", 배원병, 권영두, 김용연, 김재환, 김철,양성모, 조용주, 한티미디어, 2009. (原典) “Mechanical Design", Ansel C. Ugural, McGraw-Hill, 2005.

K7: "기계설계", 김영진, 김현수, 이건상, 최재붕, (주)한국맥그로힐, 2009. (原典) “Mechanical Engineering Design 7th Edition", Joseph E. Shigley, Charles R. Mischke, Richard G. Budynas, McGraw-Hill, 2006.

J1: “機械設計学 第2版”, 網島真男, 下間賴一, 肥田 昭, 坂口一彦, 林 和宏, オーム社, 2006.

J2: “機械要素設計 第2版”, 倉西正嗣 監修, オーム社, 2010.

J3: “改訂新版 機械設計法”, 稲田重男, 川喜多隆, 本荘恭夫, 朝合書店, 1983.

J4: “機械設計法 第2版”, 塚田忠夫, 吉村靖夫, 里崎 茂, 柳下福藏, 森北出版, 2002.

J5: “機械設計法”, 三田純義, 朝比奈奎一, 黒田孝春, 山口健二, コロナ社, 2000.

J6: “大学演習 機械要素設計 改訂版” 吉沢武男, 裳華房,1995.

J7: “機械設計法”, 日本材料学会編, 日本材料学会, 2001.

J8: "機械設計工学 1 要素と設計”, 瀬口靖幸, 尾田十八, 室津義定, 培風館, 1997,

E1: "Machine Elements in Mechanical Design" 4th ed., Robert N.,Mott, Prentice Hall, 2004.

表 3 教科書の寸法, ページ・図・式・演習問題の数

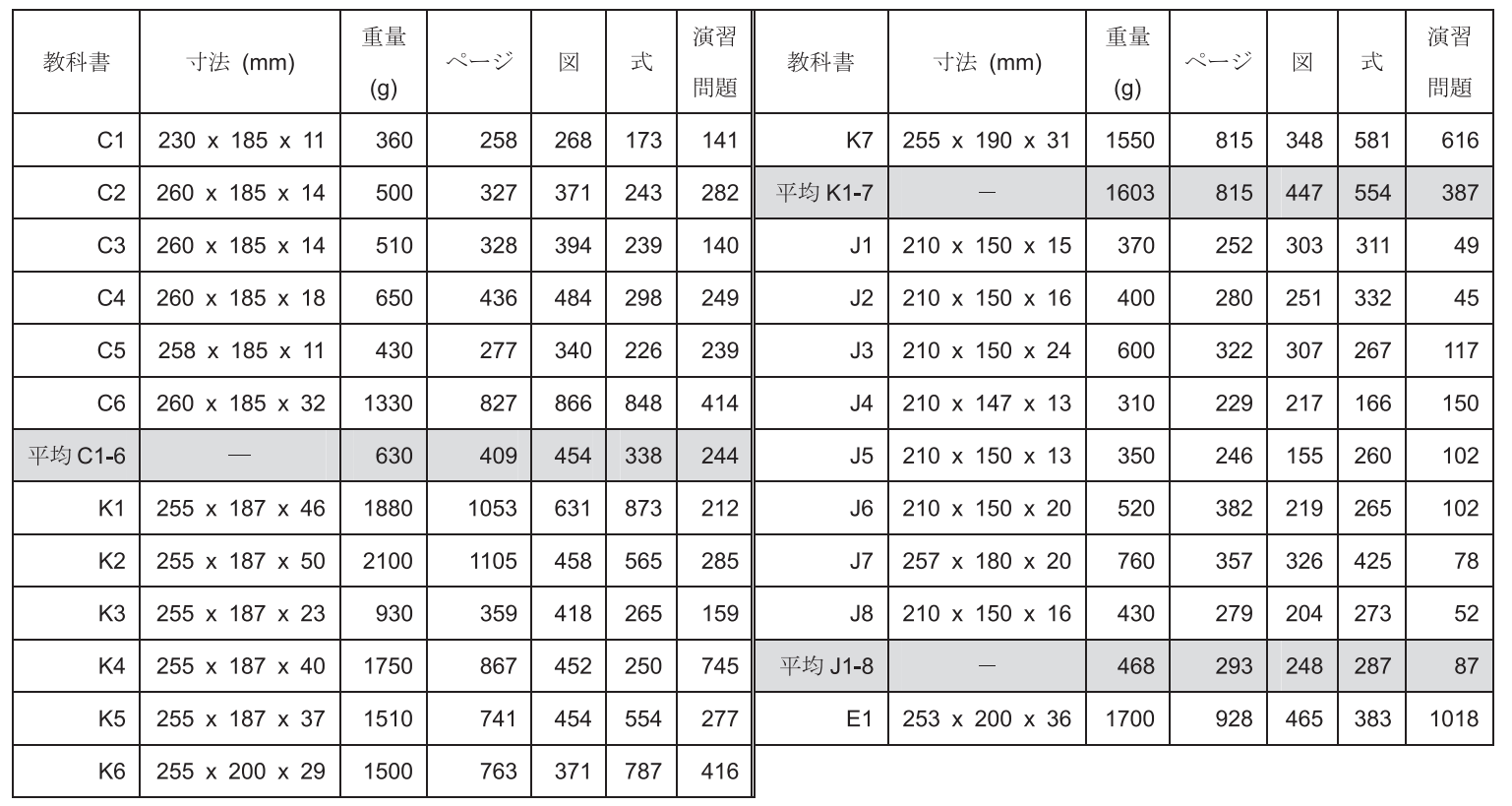

15回（演習込みで30回）の授業が行われている.

したがって韓国では，各要素の重要な箇所が授業で 解説され, 学生は詳細を教科書で自学している。一方, 日本の教科書は「要素の原理」を中心にコンパクトに まとめられているので, 更なる学習のためにはハンド
ブックや参考文献が必要になる.

\section{2 図}

機械設計の教科書において，図は明確な理解を促す ためには必要不可欠で, 工学書の中では比較的図が多 い書籍である。その図は原理を示す概略図, 規格品の 
形状を示す部品図, 要素の適用例を示す組立図などに 分類できる．中国語，韓国語，英語の教科書の図の数 は日本のものより多い (表 3 参照).

日本の教科書では概略図が多く, 中国や韓国のもの では規格や要素の応用例を示す詳細な図が多い。この ような図の様式の違いは「教科書が基礎と実用のどち らに重点をおくか」に関係している。図 1 は韓国の教 科書 [K 2] にある詳細図の一例である。この種の「軸 継ぎ手」は日本の教科書では，まず紹介されない，図 2 は中国の教科書 [C 2 ] にある実用例を示している. このような複雑な眓を解説するために，図を収録した CD教材 [C 2, C 5 ] が準備されている.

英語を原典とする教科書では斜投影図が多く，正投 影図が多い日本などの国々と異なる．複数の投影図か ら立体をイメージする正投影法は図学・製図教育に扮 いてトレーニングを要する。アメリカでは 3 次元 $\mathrm{CAD}$ の普及が早く,「視覚的に理解しやすい図法が広く利用 されている」という社会背景が理由として考えられる.

\section{3 演習問題}

演習問題は設計過程の理解と技術者としての技量を 高めるためには必要である。一般に中国語, 韓国語, 英 語の教科書には，日本語のものより多くの演習問題が 掲載されている (表 3 参照)。中国および韓国の教科書 の演習問題は機械要素の実用的な例が多く, 応用能力 を高めることを意図している．図 3，4 は中国の教科 書 [C 2 ] に打ける実用的な演習問題の例で，それぞれ 「製図の間違い探し」と「実際の図面からの強度計算」 である. また，計算問題以外に大多数の教科書で「理 由を述べる論述問題」が採用されている，更に，「空欄 を埋める問題」や「○×による問題」のように学習者

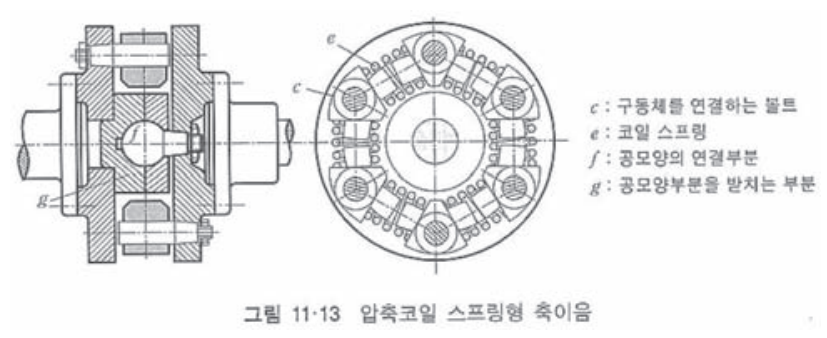

図 1 圧縮コイルばね型軸継ぎ手（韓国）

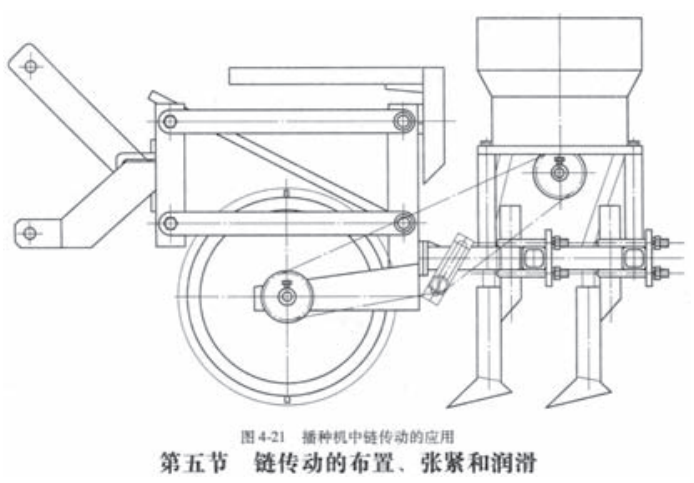

図 2 種蒔き機のチェーン伝動におけるアイドラと潤滑 (中国)
自身の理解を簡単にチェックできる問題などもある. 一方, 日本のものは学習者自身の理解を確認するため の基礎的な計算問題が多く, 解答では導出過程を丁寧 に解説している. 日本以外の問題数が多い教科書では, スペースの制約から「解答なし」や「解答のみ」のも のが多くある.中国には,「教科書に沿った教員用の指 導書」があり, これらは市販されている。 この指導書 には教科書の解答や他の例題が収録されている ${ }^{10)}$.

\section{4 第 1 章の内容}

機械設計の教科書の第 1 章には, 各機械要素に共通 な基礎知識（たとえば強度計算，材料の性質，公差・ はめあい，規格・標準化など）が解説される．「他にど のような項目を含めるか」については著者の考えに依 存している，原典をアメリカとする教科書では, 規格 と標準化についてほとんど述べられていない，そのか わりに, これらの教科書では応力解析や材料強度（破 壊）に焦点（全ページの40\%）が当てられている。機 械設計は力学を理論的な基礎にしており, 力学の後に 機械設計を学習する.しばしば授業において, 学生の 力学に対する理解が不十分な場合がある.このような 場合に力学の解説が多い教科書を用いると, 教員は関 連する部分を簡単に復習できる。

\section{5 教科書中の機械要素の学習順}

機械要素は次の 5 つの種類に分類できる。すなわち 締結要素（ねじ, 溶接, リベットなど）, 伝達要素（軸, 歯車, ベルト車など), 案内要素（軸受, ガイドなど), 制御要素 (クラッチ, ブレーキなど), 緩衝要素 (ば ね, ダッシュポットなど）である。これらの要素の中 で締結要素を最初に学習する方が, 駆動系を学習する より容易である。なぜなら, 前者は要素が固定されて

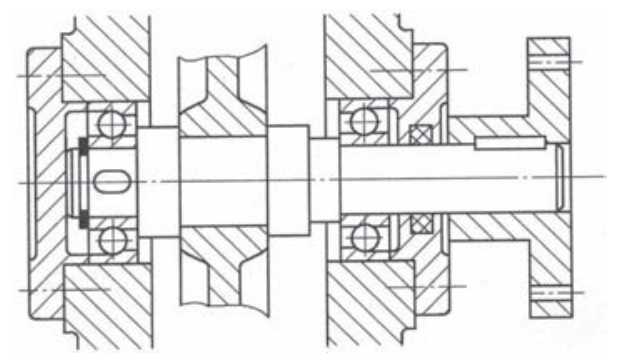

図 3 組み立て不可による図面の間違い（中国）

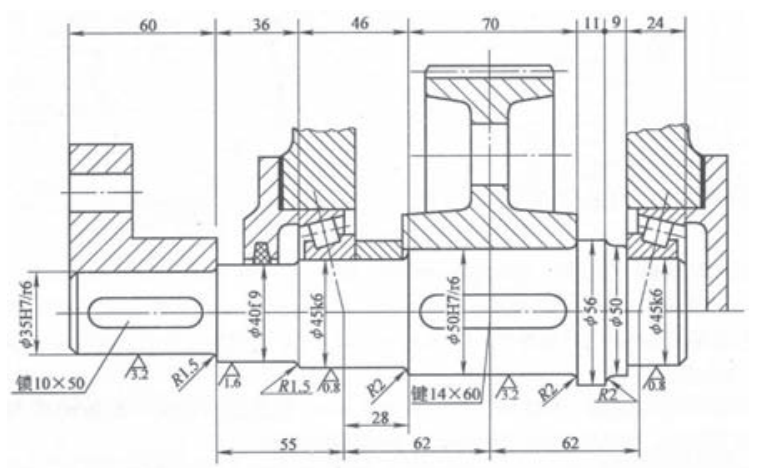

図 4 安全率からの軸の強度評価（中国） 
いるため静力学を基礎にしているのに対し, 後者は要 素自体が運動するため運動学と動力学の知識が必要に なる．実際の設計では駆動系を最初に設計し，その後 それらを支える構造について締結要素を用いて設計す る. 多くの教科書は表 4 の「日本の教科書 [J 3 ] 」の ように, 締結要素から学習し始める. 中国の教科書の 中には歯車（駆動系）を早い段階で学習し，より実際 の設計に近い形で学習するようにしたものがある（表 4 参照).

伝達要素の中で歯車は, 歯形が数学的なインボリュ 一ト曲線であるため, 特に難しい内容である. 歯車の多 くの特性はこのインボリュート関数に基づいている. また, 転位歯車や歯車の強度設計では複雑な設計過程 や弾性学の難しい概念を必要とする。中国の教科書の 中にはインボリュート関数の数学的な説明や難しい理 論を省略したものがある。難しい内容を省略すること は実用的な設計教育の 1 つの手法と言える.

歯車列はその構造から歯車の応用と考えられるが, その動きは容易に理解できる. 表 4 に示すような中国 の教科書の章立ては機械要素の構造を重視する従来の 教育方法とは異なる教育方法のヒントになる.

\section{6 単位と規格}

日本, 中国では国際単位系（SI単位）が広く用いら れているが，アメリカやイギリスの機械産業ではヤー ド・ポンド法がいまだにかなり用いられている。これ は, 機械工学の分野では現場で稼動している機械を保 守のために, 従来からある部品や規格化された機械要 素を供給するためである。これらの国々から出版され る教科書では,「力学や物理などの自然科学では系統だ ったSI 単位系」,「機械設計の教科書は両方の単位系」

表 4 教科書中の機械要素の掲載順

\begin{tabular}{|c|c|c|c|}
\hline 中国 [C1] & 中国 [C2] & 中国 [C3] & 日本 [J3] \\
\hline 平面機械 & 概説 & 平面機構分析 & \multirow{3}{*}{$\begin{array}{l}\text { 機械設計の基礎 } \\
\text { (規格, 強度設 } \\
\text { 計, 安全率) }\end{array}$} \\
\hline 平面連 機構 & 歯車 (機構, 概要) & 平面連関 & \\
\hline 凸カム & 巻掛伝動 & 凸カム & \\
\hline 歯車基礎 & チェーン & 歯車基礎 & \multirow{2}{*}{$\begin{array}{l}\text { ねじ, ねじ部 } \\
\text { 品, ピン }\end{array}$} \\
\hline 歯車列 & ねじ & 歯車列 & \\
\hline 間久運動 & 歯車(強さ) & 間久駆動 & \multirow{2}{*}{$\begin{array}{l}\text { リベット, リベ } \\
\text { ット継手 }\end{array}$} \\
\hline 調速回転体平衡 & ウォーム歯車 & 軸系 & \\
\hline 巻掛伝動 & 軸 & 回転平衡 & 溶接継手 \\
\hline チェーン伝動 & 転がり軸受 & 速度制御 & 軸および軸継手 \\
\hline \multirow{2}{*}{$\begin{array}{l}\text { 歯車伝動強度 } \\
\text { 設計 }\end{array}$} & 滑り軸受け & 応力, 強度 & 軸受 \\
\hline & 軸継手 & ねじ, ピン, キー & 巻掛け伝動装置 \\
\hline \multirow{2}{*}{$\begin{array}{l}\text { 締結 (ねじ, ピ } \\
\text { ン, リベット) } \\
\end{array}$} & キー,スプライン & 巻掛伝動 & 歯車 \\
\hline & ねじ & チェーン & ばね \\
\hline \multirow{2}{*}{$\begin{array}{l}\text { 軸受 (転がり軸 } \\
\text { 受, 滑り軸受) }\end{array}$} & ピン & 歯車伝動 (強さ) & \multirow{2}{*}{$\begin{array}{l}\text { クラッチ, ブレ } \\
\text { 一キ, つめ車 }\end{array}$} \\
\hline & ばね & ウォーム歯車 & \\
\hline 軸継手 & & 軸 & \multirow{2}{*}{$\begin{array}{l}\text { 管, 管継手, 弁, } \\
\text { 漏止め } \\
\end{array}$} \\
\hline 軸 & & 滑り軸受 & \\
\hline ばね & & 転がり軸受 & 生産設計 \\
\hline \multirow[t]{2}{*}{ 伝動系設計 } & & 軸継手 & \\
\hline & & ばね & \\
\hline
\end{tabular}

が用いられている. 単位の変換表が準備されているが, ヤード・ポンド法は初学者に混乱をもたらす。

同様な問題は工業規格においても起こる. 調査対象 国はそれぞれ自国の工業規格をもっている，台湾で使 用されている教科書 $\mathrm{E} 1$ および韓国の K $5-\mathrm{K} 7$ では, ANSI（米国規格協会）規格が紹介されている．また， 代表的な製造企業名が紹介されているが，日本では馴 染みが薄い. したがって, 入手可能な規格品が教科書 と異なるなど学生の混乱が予想される。これらは海外 で出版された教科書を用いる際のデメリットになる。

\section{4. 考察}

\section{1 教科書の言語について}

台湾の大学では英語の教科書が用いられ, 中国語に よる授業が行われている，また，理解を助けるための 参考書は中国語で出版されている。体では中央教育 審議会が大学のグローバル化の観点から英語による授 業を増やすように答申している ${ }^{11)}$. 「英語による教育は 国際的なコミュニケーションの観点ではメリットがあ り」,「内容を明確に理解するためには母国語によるも のが有効」と言えよう。教育の効率から考えると台湾 のように「英語のテキストを用いて母国語による授業」 が「英語による授業」より導入が容易で現実的な方法 と考えられる．このようなときには日本で多く出版さ れている易しい専門書は理解の助けになり得る.

台湾では，高等学校までは母国語のテキストを使用 しているので, 台湾の大学 1 年生は英語の教科書に対 応するために多くの時間と労力を割いている.「日本の 大学 1 年生が勉強の習慣から急激に遠ざかる」現状に 対して参考になるように思える.

\section{2 実用性と学問性}

機械設計は理論を実際問題に適用するために理論的 側面と実用的側面の両方が常に必要になる。したがっ て設計教育において，理論と実用のどちらを重視する かについて意見の分かれるところである．教員がこれ ら 2 つのアプローチから 1 つを選ぶとき, 学生の能力, 教育方針, 産業界の要求などの要素を考慮する必要が ある．以上の他に関連技術の進歩に応じて，次のよう な考え方も参考にする必要がある.つまり, 工学的に 確立した領域では, 多くの設計技術を教える場合には 実用的な手法の教授は習得の近道になり得る。一方， 発展途上にある分野については原理に基づいた理論的 なアプローチが将来の発展性に対して有益である。そ れゆえ, 教員は理論的か実用的かについてその長所短 所を理解して, 教科書の内容を時代の変化に応じて見 直すべきであろう。

学生は異なる設計手法を通してしだいに設計のプロ セスや考え方に対して理解を深める。したがって, 発 展的な内容は, 授業中に教員によって重要な部分につ いて解説がなされるならば，有益である。この点, 日 
本の教科書では発展的な内容が削られている分, コン パクトで「何が本質的か」を理解し易い. ただし, こ のような教科書を用いていると,「記述されている内容 が全てである」という錯覚に陷り易い. 特に日本の学 生は他の参考書により,「機械設計はいかに広範囲の知 識を必要とし，深い考えに基づいているか」を知るべ きであろう。

\section{3 力学から設計のつながり}

中国の力学の教科書には, 機械系の学生を対象とし たものがある ${ }^{7)}$. この教科書では,「剛体の力学から変 形体の力学へつながり」をもたせ，「機械への適応例」 (図 5 参照)が多く掲載されている。図 5 はねじ山の斜 面の力学で, 通常では機械設計の教科書で解説される 内容である. 日本の力学の教科書は「力学を必要とす る全ての学生」を対象としており, 理学部出身の教員 によるものが多い. 力学の内容を機械系の学生向けに 絞り込んでも多くの需要があるから成立するのかもし れないが, 日本でも一考に価する。

\section{5.おわりに}

自然科学は普遍的であるので，教科書の内容の違い は著者の執筆方針や編集方針の違いのみによって生じ る.しかし, 工学は規格・単位, 部品調達・製品の利 用，産業政策など社会と関係があるため，工学書は国 によって異なる面がある．極東アジア諸国の大学で使 用されている機械設計の教科書を調査して以下の知見 を得た。

(1)中国では,「学部生をエンジニアとして教育する」と いう国家的な方針が貫かれている。この考えに基づい て教科書は実用的な内容で組織的に編集されている. (2)韓国の教科書は分量が多く広範な内容を含んでいる.

学習者は自学により有益な情報を得る機会がある.

(3)台湾では英語の教科書を使用しており，産業のグロ ーバル化に適応している.

(4)日本語の教科書は簡潔にまとめられているので, 理 解を広げるためには授業で発展的な内容を補うべき であろう。

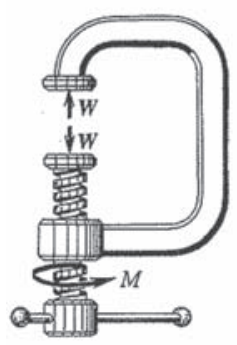

(a)

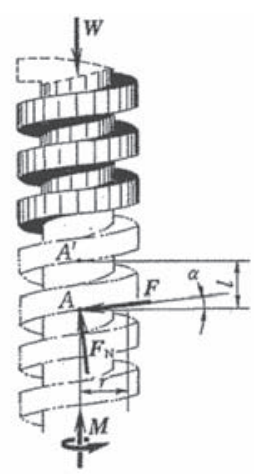

(b)
图 4-20 蝶旋器棫及其简化模㤠

図 5 ねじの力学 (中国)
なお, 本研究は平成 22 年度科学研究費（極東アジア における機械設計に関するテキストの状況調査と日本 の課題）の補助を受けて実施した。

\section{参 考 文 献}

1 ）有光 隆，八木秀次：学習者の視点からみたテキ ストの評価, 日本工学教育協会年次大会, pp.360361, 2009

2 ）日本青少年研究所報告書：高校生の勉強に関す る調査一日本・アメリカ・中国・韓国の比較一, Webページ, http://www1.odn.ne.jp/youth-study/ reserch/index.html, 2010, 参照日：2012-12-20

3 ）総務省統計局データベース, Webページ, http:// www.stat.go.jp/, 2013, 参照日：2013-1-25

4 ）文部科学省データベース, Webページ, http:// www.mext.go.jp/, 2013, 参照日：2013-1-21

5 ）中華民国(台湾)教育部データベース, Webページ, http://english.education.edu.tw/, 2011, 参照日 : 2013-1-23

6 ）2010年全国教育事业发展统计公报, Webページ, http://news.xinhuanet.com/edu/2011-07/06/ c_121629066.htm, 2010, 参照日：2013-1-10

7 ) 范 鉄珊 (主編): 工程力学教程 (I), (II), 高等教育 出版社, 1998

8 ) 岡村志嘉子 : 台湾の『大学教育政策白書』(全訳), 国立国会図書館ディジタル化資料, http://dl.ndl. go.jp/info:ndljp/pid/1000002, pp.60-80, 2003, 参 照日：2012-12-2

9 ）金 永鐘：韓国における理工系離れと最近の大学 生の就職状況について, 工学教育, 55-6, pp.7278, 2007

10）たとえば, 郭 維林, 焦 艶芳 : 机械設計 同歩補 導及習題全解, 中国水利水電出版社, 2009

11）中央教育審議会大学分科会：「『留学生 30 万人計 画』の骨子」とりまとめの考え方に基づく具体的 方策の検討, 文部科学省Webページ, http:/ /www. mext.go.jp/b_ menu/ shingi/chukyo/chukyo4/ houkoku/attach/1249706.htm, 2008, 参照日： 2013-1-12

\section{著者紹介}

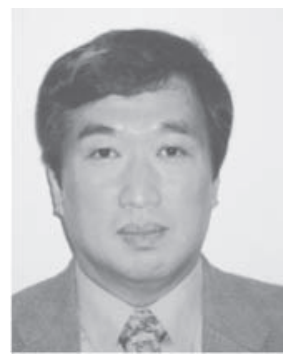

有光 隆

1978年, 徳島大学工学部精密機械工学科 卒, 徳島大学工学研究科修士課程修了, 京 都セラミック株式会社, 高知工業高等専門 学校機械工学科助手を経て愛媛大学工学 部講師. 現在, 愛媛大学大学院理工学研究 科准教授

所属学会：日本機械学会, 日本材料学会, 日本複合材料学会

専 門：材料力学 